\title{
Effects of nitrate and the pathogenic water mold Saprolegnia on survival of amphibian larvae
}

\author{
John M. Romansic*, Kristin A. Diez, Elise M. Higashi, Andrew R. Blaustein \\ Department of Zoology, Oregon State University, Corvallis, Oregon 97331, USA
}

\begin{abstract}
We tested for a synergism between nitrate and Saprolegnia, a pathogenic water mold, using larvae of 3 amphibian species: Ambystoma gracile (northwestern salamander), Hyla regilla (Pacific treefrog) and Rana aurora (red-legged frog). Each species was tested separately, using a $3 \times$ 2 fully factorial experiment with 3 nitrate treatments (none, low and high) and 2 Saprolegnia treatments (Saprolegnia and control). Survival of $H$. regilla was not affected significantly by either experimental factor. In contrast, survival of $R$. aurora was affected by a less-than-additive interaction between Saprolegnia and nitrate. Survival of $R$. aurora was significantly lower in the Saprolegnia compared to the control treatment when nitrate was not added, but there was no significant difference in survival between Saprolegnia and control treatments in the low and high nitrate treatments, consistent with increased nitrate preventing Saprolegnia from causing mortality of $R$. aurora. Survival of A. gracile followed a similar pattern, but the difference between Saprolegnia and control treatments when nitrate was not added was not significant, nor was the nitrate $\times$ Saprolegnia interaction. Our study suggests that Saprolegnia can cause mortality in amphibian larvae, that there are interspecific differences in susceptibility and that the effects of Saprolegnia on amphibians are context-dependent.
\end{abstract}

KEY WORDS: Pathogen $\cdot$ Saprolegnia $\cdot$ Amphibian

Resale or republication not permitted without written consent of the publisher

\section{INTRODUCTION}

Infectious diseases can bring about population declines and local host extinctions, contributing significantly to the global 'biodiversity crisis'. Emerging infections involving novel pathogens or bringing established pathogens in contact with naïve host populations often have particularly drastic effects on their hosts (Daszak et al. 2000, Cleaveland et al. 2002, Harvell et al. 2002, Altizer et al. 2003). In addition, pathogens capable of infecting multiple species may cause extinctions, as more resistant host species act as reservoirs of infection, preventing the demise of the pathogen along with its susceptible hosts (e.g. Gog et al. 2002, McCallum \& Dobson 2002). Furthermore, the effects of pathogens on hosts are often context-dependent (e.g. Grossholz 1992, Kiesecker \& Skelly 2001, Mitchell et al. 2002). For example, both biotic and abiotic stressors may act synergistically with pathogens to increase the adverse effects on hosts. Thus, if both stressors and pathogens are present, the effects on hosts may be greater than if either factor acted alone (Guth et al. 1977, Brown \& Pascoe 1989, Khan 1990).

In several locations, amphibians may exemplify systems in which stressors and pathogens interact, thereby influencing population dynamics. The documentation of amphibian population declines (Alford \& Richards 1999, Houlahan et al. 2000, Stuart et al. 2004) describes a number of factors as contributing to these declines, including abiotic and biotic stressors and pathogens (Alford \& Richards 1999, Collins \& Storfer 2003, Semlitsch 2003, Blaustein et al. 2004). Clearly, causes for amphibian population declines appear to be context-dependent and complex, often with more than one factor involved (Blaustein \& Kiesecker 2002). It is also becoming clear that some amphibian populations have been severely impacted by 1 or more pathogens (Daszak et al. 2003). It is likely that the effects of these pathogens are influenced by co-factors (Taylor et al. 1999, Blaustein \& Kiesecker 2002, Kiesecker 2002, Christin et al. 2003, Gendron et al. 2003) 
Saprolegnia, a water mold, is one important pathogen found in many amphibian populations (e.g. Strijbosch 1979, Banks \& Beebee 1988, Blaustein et al. 1994). Furthermore, Saprolegnia-associated mortality appears to increase in the presence of abiotic stressors (Strijbosch 1979, Banks \& Beebee 1988, Kiesecker \& Blaustein 1995, Kiesecker et al. 2001a).

Saprolegnia (family Saprolegniaceae) is both saprobic and parasitic, obtaining nutrition from decaying organic matter or living hosts (Seymour 1970). Saprolegnia infects a wide variety of organisms, including insects, turtles, fishes, and amphibians (MacGregor 1921, Seymour 1970). In amphibians, embryos and larvae can become infected (Bragg \& Bragg 1958, Walls \& Jaeger 1987, Blaustein et al. 1994). Saprolegnia-infected embryos of fishes and amphibians become covered with visible white hyphal filaments and usually do not hatch (Blaustein et al. 1994). Infection can spread via contact from growing hyphae (in the case of immobile hosts such as amphibian egg masses) or through colonization by free-swimming zoospores (Wood \& Willoughby 1986). Transmission can occur between species, for example, between fishes and amphibians (Kiesecker et al. 2001b). Fishes and amphibians may also be infected by Saprolegnia via contact with infected soil (Kiesecker et al. 2001b). Host species show strong interspecific variation in their susceptibility to infection (Richards \& Pickering 1978, Wood \& Willoughby 1986, Kiesecker \& Blaustein 1995, 1997). Factors such as water temperature, $\mathrm{pH}$, pollution, exposure to UV-B radiation, injury from biting, silt, and host behavior may modify the effects of Saprolegnia on its hosts (MacGregor 1921, Strijbosch 1979, Walls \& Jaeger 1987, Banks \& Beebee 1988, Carballo \& Muñoz 1991, Bly et al. 1993, Pickering 1994, Carballo et al. 1995, Kiesecker \& Blaustein 1995, 1997, Lefcort et al. 1997). Saprolegnia may influence community structure by altering competition between hosts (Kiesecker \& Blaustein 1999). Saprolegnia has a world-wide distribution (Wood \& Willoughby 1986, Blaustein et al. 1994, Kiesecker \& Blaustein 1997). This ubiquitous distribution is influenced by the widespread introduction of hatchery-raised fishes that carry and transmit Saprolegnia to other species (Blaustein et al. 1994, Kiesecker et al. 2001b).

The purpose of this study was to examine amphibian larvae for susceptibility to mortality from Saprolegnia and to test for a possible synergism between Saprolegnia and nitrate, an important stressor on amphibian populations. Nitrate contamination is of global importance. In $2000,87 \times 10^{6}$ metric tons of nitrogen were used as fertilizer in agriculture (Tilman et al. 2001). Nitrogen fertilization and sewage from humans and livestock are major sources of nitrate (Steinheimer et al. 1998, Tilman et al. 2001). In the 1990s in the Willamette Basin of Oregon about 63000 t nitrate were applied (Rinella \& Janet 1998). Ninety-eight percent of stream samples in the Willamette Basin contained detectable nitrate concentrations (0.054 to $22 \mathrm{mg} \mathrm{l}^{-1}$ ) (Wentz et al. 1998). Anthropogenic nitrate enters aquatic ecosystems via runoff, groundwater, and sewage discharge (e.g. Giblin \& Gaines 1990, Steinheimer et al. 1998, van Lanen \& Dijksma 1999, Zhilang et al. 2003). There is a direct correlation between nitrate concentration and the proportion of the drainage area in agriculture. Nitrate concentrations vary seasonally, with highest concentrations coinciding with the beginning of rainfall induced run-off in the autumn and early winter (Wentz et al. 1998).

Anthropogenic nitrate contributes to eutrophication and can cause nitrate concentrations to reach toxic levels (OECD 1982, Rouse et al. 1999). Nitrate is toxic to a variety of organisms, including humans (Comly 1945, Lee 1970, Muir et al. 1991, Camargo \& Ward 1995). There are well-documented effects on the susceptibility of amphibian species to nitrogenous fertilizers (e.g. Hecnar 1995, Marco et al. 1999, Rouse et al. 1999, Hatch et al. 2001). Effects of nitrate on amphibians include mortality, impaired feeding ability, reduced growth, slowed development, altered behavior, and methemoglobinemia (Huey \& Beitinger 1980, Baker \& Waights 1993, Watt \& Oldham 1995, Marco et al. 1999, Hatch \& Blaustein 2000, Hatch \& Blaustein 2003). Nitrate can also interact with UV-B radiation to decrease growth or survival (Hatch \& Blaustein 2003). Furthermore, nutrient enrichment from nitrogenbased fertilizers may alter community dynamics by increasing the abundance of herbivores, such as snails that are hosts for parasites linked to amphibian deformities (Johnson et al. 2002, Chase 2003a,b, Johnson \& Chase 2004).

\section{MATERIALS AND METHODS}

Embryos of the northwestern salamander Ambystoma gracile, Pacific treefrog Hyla regilla and redlegged frog Rana aurora (hereafter, Ambystoma, Hyla, and Rana) were collected in 2002. Ambystoma and Rana were collected on 10 February and 17 March, respectively, at Coast Pond (approximately $20 \mathrm{~km}$ south of Walport, Lincoln County, Oregon, USA). Hyla were collected on 10 March from a pond at Baker Beach (approximately $10.5 \mathrm{~km}$ north of Florence, Lane County, Oregon, elevation about $12 \mathrm{~m}$ ). Whole clutches of Ambystoma and Hyla were collected, while portions of Rana clutches were collected.

Amphibians were maintained and hatched in the laboratory at 13 to $17.5^{\circ} \mathrm{C}$ in tanks filled with dechlorinated tapwater treated with Novaqua ${ }^{\circledR}$ and Amquel ${ }^{\circledR}$ water conditioners. These conditioners do not remove nitrate or 
nitrite. Each species was kept separately. Hyla and Rana were reared in tanks containing about $30 \mathrm{l}$ of water and Ambystoma were reared in tanks containing about 8 of water. Approximate densities of larvae were 6.3, 2.1 to 3.1, and 12.5 individuals $\mathrm{l}^{-1}$ for Hyla, Rana, and Ambystoma, respectively. Frog larvae were fed a ground mixture of alfalfa pellets and Tetramin fish flakes. Ambystoma were given Artemia (brine shrimp). A natural photoperiod was provided during the maintenance and experimental periods in the form of artifical light combined with natural daily sunlight through unshaded windows.

Each species was tested in a separate experiment. Each experiment used a $3 \times 2$ fully factorial design to manipulate nitrate and Saprolegnia. There were 3 nitrate treatments (no nitrate, low nitrate, and high nitrate) and 2 Saprolegnia treatments (Saprolegnia and control). Treatments were assigned to units randomly, and larvae were added to units haphazardly with respect to treatment. For each species, there were 5 replicates of each treatment combination. Thus, there were 30 units per species, for a total of 90 units.

Experimental units consisted of plastic boxes (dimensions: $31 \times 18 \times 8 \mathrm{~cm}$ ) containing $2 \mathrm{l}$ of water from one of 3 stock solutions (no nitrate, low nitrate, and high nitrate stock solutions). We added $0.29 \mathrm{ml} \mathrm{l}^{-1}$ of Novaqua ${ }^{\circledR}$ and $0.29 \mathrm{ml} \mathrm{l}^{-1}$ of Amquel $^{\circledR}$ to each stock solution. We added sodium nitrate to the low nitrate and high nitrate stock solutions to achieve nominal nitrate concentrations of 0,5 , and $20 \mathrm{mg} \mathrm{l}^{-1}$ in the no nitrate, low nitrate, and high nitrate treatments, respectively.

Ten larvae were added per unit for Hyla and Ambystoma, while 7 larvae were added per unit for Rana. Larvae were added to units, and treatments were applied on 14 April 2002. Hyla and Rana ranged in age from about 2 to 5 and 7 to 9 wk post-hatching, respectively. Gosner developmental stages (Gosner 1960) were 25 to 28 in Hyla and 25 to 30 in Rana. The oldest Ambystoma larvae used in experiments were $25 \mathrm{~d}$ post-hatch.

Larvae were chosen for experimentation haphazardly. For Ambystoma, 1 larva was chosen haphazardly from each of 10 clutches, and individuals that appeared to be small and recently hatched were excluded. Hyla were chosen from 2 tanks, 1 containing larvae from 12 clutches and 1 containing larvae from 13 clutches. Rana were chosen from 4 tanks and from 4 to 8 clutches.

Saprolegnia was isolated from a water sample taken next to a Rana aurora embryo mass in Coast Pond on 10 February 2002. Isolation of Saprolegnia was achieved using sterile hemp seeds and YpG (yeast-glucose) agar media (Fuller \& Jaworski 1987). Saprolegnia was prepared for experiments by placing a hemp seed laden with Saprolegnia into a Petri dish (diameter $=85 \mathrm{~mm}$, height $=12 \mathrm{~mm}$ ) filled approximately half full with ultrapure water and containing 7 sterile hemp seeds. Dishes were incubated at $\sim 13$ to $15^{\circ} \mathrm{C}$ for $6 \mathrm{~d}$. These hemp seeds, laden with Saprolegnia, were used in Saprolegnia treatments. Three seeds were added to each unit in the Saprolegnia treatment. Immediately prior to the experiment, seeds were connected by Saprolegnia hyphae. Seeds were disconnected and added to units haphazardly. Units in the control treatment received 3 sterile hemp seeds. Addition of sterile seeds was haphazard with respect to nitrate treatment.

Leftover seeds laden with Saprolegnia were placed in a refrigerator $\left(\sim 4\right.$ to $\left.5^{\circ} \mathrm{C}\right)$ at the start of the experiments. Non-spherical zoosporangia were counted $4 \mathrm{~d}$ later using a dissecting microscope on 5 seeds with heavy growth, selected haphazardly. Number of zoospores per seed (mean \pm SE) was 16.6 \pm 4.0 . Spherical zoosporangia may have been present (Seymour 1970); however, they would have been indistinguishable from oogonia under the dissecting microscope. Since the number of spherical zoosporangia was not quantified, our counts of zoosporangia may be underestimates.

Within $5.5 \mathrm{~h}$ of addition of larvae to units and application of Saprolegnia treatments, units from 1 of each treatment combination were selected haphazardly for each species and a water sample was taken to obtain measurements of initial water quality. Conductivity, total alkalinity, and calcium hardness were measured in subsets of water samples. We measured $\mathrm{pH}$ for every water sample.

To minimize handling stress of animals in the experiments, initial measurements of their total length and mass were not taken. Instead, on 15 April, unused larvae from the same stocks were selected (in the same manner that larvae were selected for experimentation) and measured to obtain estimates of total length and mass of the larvae in the experiments (Table 1).

During the experiment, anurans were fed ad libitum a ground mixture of alfalfa pellets and Tetramin fish

Table 1. Hyla regilla, Rana aurora and Ambystoma gracile. Measurements of total length (mean $\pm 1 \mathrm{SE}$ ) and mass (mean $\pm 1 \mathrm{SE}$ ) from laboratory stocks of amphibian larvae

\begin{tabular}{|lccc|}
\hline Species & Total length $(\mathrm{mm})$ & $\mathrm{N}$ & Mass $(\mathrm{g})$ \\
\hline H. regilla & $12.7 \pm 0.3$ & 32 (8 batches of 4 larvae each) & $0.03^{\mathrm{a}}$ \\
R. aurora & $23.5 \pm 0.7$ & 23 (23 larvae) & $0.14 \pm 0.02$ \\
A. gracile & $16.6 \pm 0.4$ & 30 (10 batches of 3 larvae each) & $0.03^{\mathrm{a}}$ \\
a SE could not be calculated because larvae were massed in batches & \\
\hline
\end{tabular}


flakes. On 20 April, Ambystoma were given Artemia (brine shrimp). The experiment was checked at least once per day. Live larvae were monitored visually for hyphal structures consistent with descriptions of Saprolegnia growth on amphibian larvae (Bragg \& Bragg 1958, Bragg 1962). Dead larvae were removed and examined for hyphal structures with a dissecting microscope. Each experiment lasted for 7 d. Surviving larvae were anesthetized with MS-222 and sacrificed. During the experiment, laboratory temperature was maintained at approximately 13 to $15^{\circ} \mathrm{C}$.

Survival was analyzed separately for each species using ANOVA. All data met parametric assumptions on the original scale, and conversion of the data to proportion of individuals surviving, followed by arcsin square-root transformation, had negligible effects on normality and inequality of variances. Therefore, data on the original percent survival scale were used for analyses. Tukey tests $(\alpha=0.05)$ were used for pairwise comparisons between treatment combinations.

\section{RESULTS}

In Hyla, no significant effects of nitrate or Saprolegnia on survival were found (Fig 1, Table 2). In contrast, for Rana, significant effects of Saprolegnia and the interaction between nitrate and Saprolegnia were detected, although the nitrate term was not significant (Table 2). Survival of Rana is presented in Fig. 2. For Rana, in the no nitrate treatment, survival was significantly lower in the Saprolegnia treatment compared to the control treatment $(0.005<\mathrm{p}<0.01)$. However, in the low nitrate and

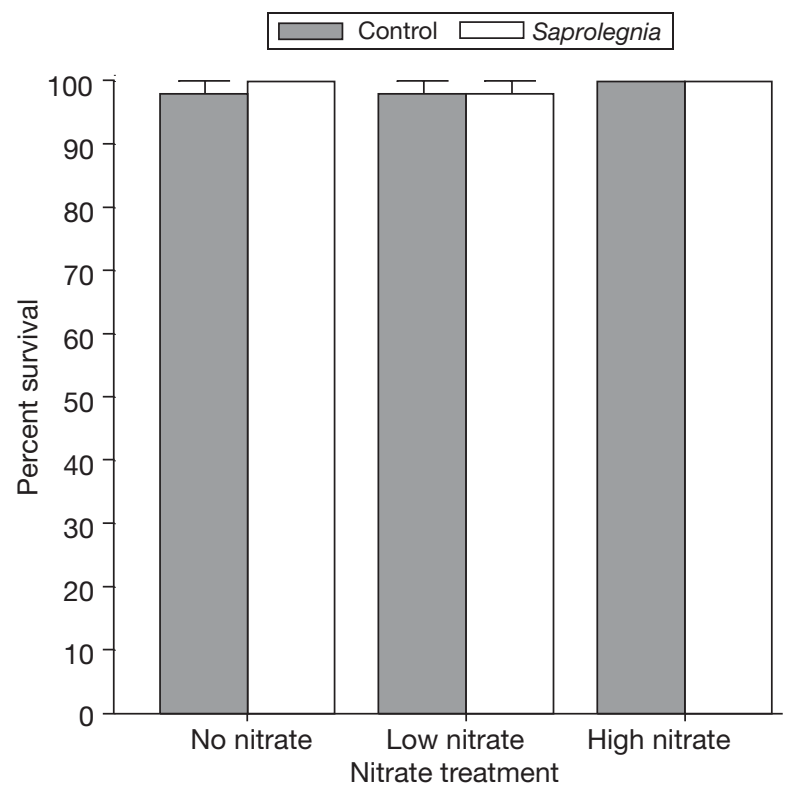

Fig. 1. Hyla regilla. Survival of larvae. Error bars are $+1 \mathrm{SE}$
Table 2. Hyla regilla, Rana aurora and Ambystoma gracile. ANOVA results for the survival of larvae of the 3 amphibian species

\begin{tabular}{|lcccc|}
\hline Source of variation & MS & df & $F$ & $\mathrm{p}$ \\
\hline H. regilla & & & & \\
$\quad$ Nitrate & 10.000 & 2 & 1.000 & 0.383 \\
Saprolegnia & 3.333 & 1 & 0.333 & 0.569 \\
Nitrate $\times$ Saprolegnia & 3.333 & 2 & 0.333 & 0.720 \\
Error & 10.000 & 24 & & \\
R. aurora & & & & \\
Nitrate & 20.408 & 2 & 0.128 & 0.881 \\
Saprolegnia & 1149.660 & 1 & 7.192 & 0.013 \\
Nitrate $\times$ Saprolegnia & 700.680 & 2 & 4.383 & 0.024 \\
Error & 159.864 & 24 & & \\
A. gracile & & & & \\
Nitrate & 13.333 & 2 & 2.667 & 0.090 \\
Saprolegnia & 13.333 & 1 & 2.667 & 0.116 \\
Nitrate $\times$ Saprolegnia & 13.333 & 2 & 2.667 & 0.090 \\
Error & 5.000 & 24 & & \\
\hline
\end{tabular}

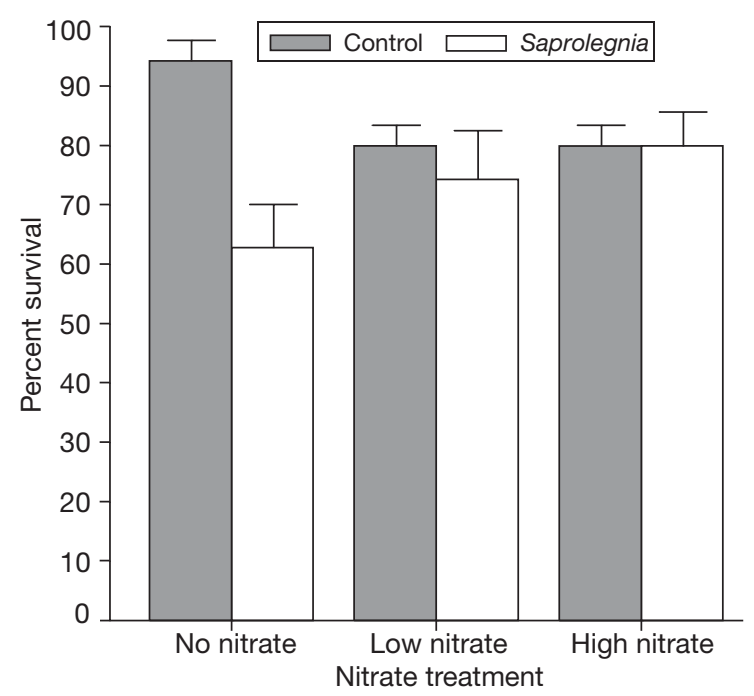

Fig. 2. Rana aurora. Survival of larvae. Error bars are $+1 \mathrm{SE}$

in the high nitrate treatments, survival was not significantly different between Saprolegnia and control treatments. Nitrate alone did not significantly affect survival (none of the differences between treatment groups were significant). However, survival was always lower when nitrate was added, compared to the no nitrate, control treatment group (no nitrate or pathogen added). One Rana individual with severe tail damage was observed being preyed upon by 2 conspecifics. It was removed and scored as dead. Scoring this individual as dead or eliminating it from the analysis did not alter the qualitative interpretations regarding Rana survival.

In Ambystoma, survival when nitrate was not added was lower in Saprolegnia compared to control treatments (Fig. 3), but all larvae, in both Saprolegnia and control treatments, survived when nitrate was added. 


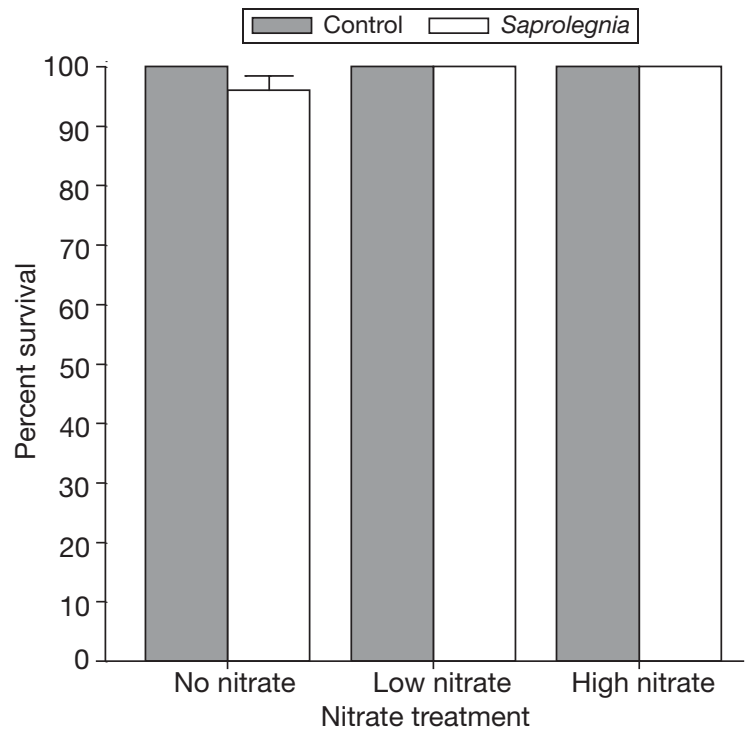

Fig. 3. Ambystoma gracile. Survival of larvae. Error bars are $+1 \mathrm{SE}$
Only 2 larvae died; both were in the no nitrate, Saprolegnia treatment. ANOVA revealed no significant effects of the treatments or their interaction; however, there were non-significant trends toward a main effect of nitrate treatment and a nitrate $\times$ Saprolegnia interaction (Table 2). Thus, there was a non-significant trend of the same less-than-additive interaction between the 2 factors that we detected in the experiment using Rana.

In Rana, 4 carcasses were observed being eaten by conspecifics, and signs of scavenging (i.e. holes in the skin or missing structures obviously due to scavenging) were observed on 25 of the 31 remaining carcasses. For an additional 2 carcasses, it could not be determined whether cannibalism was involved in causing the missing structures (this may have resulted from parasitism, e.g. from Saprolegnia, or decomposition without the involvement of cannibalism). Two larvae (1 in the no nitrate, control treatment combination and 1 in the low nitrate, Saprolegnia treatment) were observed being chewed upon by 1 or more conspecifics while still alive.

No signs of hyphal growth were observed in Hyla (Table 3). Rana carcasses had hyphal growths more often in Saprolegnia compared to control treatments in the no nitrate and low nitrate treatments, but the reverse was true in the high nitrate treatment. In contrast, hyphae were noted in live Rana more frequently in Saprolegnia than in control treatments in each of the nitrate treatments. At the end of the experiment, hyphal growths were not observed on any live Rana. It is possible that in Rana, shredded tadpole structures (e.g. muscle and connective tissue) due to scavenging by conspecifics may have been misidentified as hyphae in some cases. Both of the Ambystoma that died, which were in the no nitrate, Saprolegnia treatment combination, were covered with hyphae, but hyphae were not noted on any live Ambystoma.

Conductivity ranged from 153 to $195 \mu \mathrm{S} \mathrm{cm}^{-1}$ ( $\mathrm{n}=6$, not all treatment combinations included), total alkalinity ranged from 33 to $41 \mathrm{mg} \mathrm{CaCO}_{3} \mathrm{l}^{-1}$ ( $\mathrm{n}=5$, not all treatment combinations included), and calcium hardness ranged from 34 to $40 \mathrm{mg} \mathrm{CaCO}_{3} \mathrm{l}^{-1}$ ( $\mathrm{n}=5$, not all treatment combinations included). $\mathrm{pH}$ varied from 6.5 to 7.2 ( $\mathrm{n}=18)$. 


\section{DISCUSSION}

Our results suggest that Saprolegnia caused mortality of Rana, but only in the no nitrate treatment. This is consistent with increased nitrate preventing Saprolegnia from causing mortality of Rana. In Rana, the combined effects of nitrate and Saprolegnia were less than additive, rather than synergistic. Although determining the mechanism behind such an interaction was not a goal of this study, some possible mechanisms deserve note. Nitrate may decrease zoospore production or kill zoospores in Saprolegnia. Nitrate may also have induced a physiological response in Rana that increased their resistance to Saprolegnia.

Less-than-additive stressor-pathogen interactions have been reported previously in different organisms, including amphibians. For example, Parris \& Baud (2004) demonstrated a negative interaction between copper and the amphibian pathogen Batrachochytrium dendrobatidis. Both copper and the pathogen increased the length of the larval period in gray treefrogs Hyla chrysoscelis larvae, but the magnitude of the effect of the pathogen on larval period was lower when the copper concentration was high than it was in regimes in which there was a lower copper concentration. Parris \& Baud (2004) hypothesized that copper may have decreased the growth of the fungus on H. chrysoscelis. Poleo et al. (2004) found that aluminum and zinc decreased the number of parasites in Atlantic salmon Salmo salar. Parasite diversity and intensity in 2 snail species (Physella columbiana and Lymnaea palustris) were lower in lakes polluted by heavy metals than in reference lakes, which may have influenced competitive interactions between the 2 snail species (Lefcort et al. 2002). Riggs \& Esch (1987) and Riggs et al. (1987) studied the tapeworm Bothriocephalus acheilognathi in Gambusia affinis (mosquitofish), Notropis lutrensis (red shiners), and Pimophales promelus (fathead minnows) in a cooling pond receiving thermally and selenium-enriched fly ash from a coal-fired power plant in North Carolina, USA. Three sites were characterized as polluted, interface or unpolluted, based upon proximity to the fly ash input and selenium concentration. A complex pattern of mean number of worms per fish, mean number of gravid worms per fish, growth and biomass of worms, ratio of gravid proglottids per gravid worm, and number of eggs shed per gravid proglottid emerged (Riggs \& Esch 1987, Riggs et al. 1987). In several cases, the pattern was consistent with increased pollution causing decreased worm population size or decreased performance of individual worms (Riggs \& Esch 1987, Riggs et al. 1987).

Other stressors may also affect host-pathogen interactions. For example, high temperatures may also reduce the effects of infectious disease or even eliminate infection. Woodhams et al. (2003) found evidence consistent with high temperatures eliminating Batrachochytrium dendrobatidis infection in juvenile Litoria chloris (red-eyed treefrogs). However, the influence of temperature on amphibian diseases may not be straightforward. Aspects of diseases such as mortality from infection, time to death after exposure, and production of pathogenic propagules may show conflicting patterns with respect to temperature (Berger et al. 2004, Rojas et al. 2005).

Importantly, effects of stressor-pathogen interactions on parameters of individual hosts do not necessarily translate into corresponding effects at the level of the host population. Indeed, modeling of the influence of environmental stress on the impact of infectious disease caused by a parasite that is host specific and has a population closed to recruitment from outside the population, suggests that environmental stress that increases the susceptibility of individual hosts to the parasite is most likely to decrease the impact of the disease on the host population (Lafferty \& Holt 2003). However, if stress that increases the susceptibility of individual hosts to parasites occurs in an infectious disease system in which the parasite population is open to outside recruitment, or is not host-specific and the other host(s) are not affected by the stress, then the stress will most likely cause an increase in the impact of the disease on the host population (Lafferty \& Holt 2003). In this scheme, the ability to grow as a saprobe (as Saprolegnia can) should have the same qualitative effect on a host population as open recruitment or ability to use 1 or more alternate hosts unaffected by the stressor. Lafferty \& Holt (2003) did not model situations in which the effects of stress and an infectious disease on individual hosts were less-than-additive. However, it seems logical that if nitrate prevents Saprolegnia from affecting survival of amphibian larvae, then it will also prevent Saprolegnia from having effects on larvae that influence population-level parameters. However, effects on other life stages besides larvae may factor in to determine the combined effects of nitrate and Saprolegnia on an amphibian population, and the effects on survival of other life stages may be different from the effect on survival of larvae.

Our study concentrated on testing the separate and combined effects of nitrate and Saprolegnia on survival of amphibian larvae. Thus, we did not focus on possible sublethal effects. Nitrate and Saprolegnia may interact to influence sublethal parameters in amphibian larvae.

The nominal nitrate concentrations we used were realistic for amphibian larvae in habitats receiving fertilizer runoff. In the Willamette Valley of Oregon, average nitrate concentrations of 17.8 and $21.9 \mathrm{mg} \mathrm{N}^{-1}$ 
were reported in water samples from some crop soils receiving recommended rates of nitrogen fertilization (Brandi-Dohrn et al. 1997, Marco et al. 1999). These average values are highly toxic to some amphibians (Marco et al. 1999). Flow-weighted mean nitrate concentrations ranging from zero to $14.8 \mathrm{mg} \mathrm{l}^{-1}$ have been recorded in streams draining the English Lake District, Cumbria, England (Thornton \& Dise 1998). Average nitrate concentrations in $30 \mathrm{mg} \mathrm{l}^{-1}$ have been recorded in relatively large streams in the Great Lakes region of North America (US EPA 1998, Rouse et al. 1999). Rouse et al. (1999) suggest that such streams will typically have average nitrate concentrations lower than small ponds and ditches close to point sources of nitrate. Thus, amphibian larvae in agricultural landscapes may be exposed to nitrate levels well in excess of $30 \mathrm{mg} \mathrm{l}^{-1}$. Exposure to these levels may occur for extended periods of time (Rouse et al. 1999).

Observations of Rana carcasses suggest that the Saprolegnia treatment caused infection in the low and no nitrate treatments, but not in the high nitrate treatment. Furthermore, our results suggest Saprolegnia can kill larvae of $R$. aurora in water lacking nitrate pollution. Because most of the studies of the effects of Saprolegnia on amphibians have been examined in embryos, our study of larvae is an important step in determining the effects of this pathogen on postembryonic life history stages. The effects of Saprolegnia on amphibian populations may be far different, and possibly more severe, if the pathogen causes mortality in both embryos and larvae rather than in just 1 life stage. Recent models have shown differential effects on populations when mortality occurs in different life stages in amphibians (Biek et al. 2002, Vonesh \& De la Cruz 2002a,b).

Under the conditions of this study, Rana was susceptible to mortality from Saprolegnia when nitrate was not added, while Hyla and Ambystoma were not susceptible to mortality from Saprolegnia in any of the nitrate treatments. These interspecific differences may indicate that $R$. aurora larvae are more susceptible to Saprolegnia than larvae of the other 2 species. However, the relative susceptibilities of these species may depend on the dose of the pathogen.

Acknowledgements. Funding was provided by grants from The NSF IRCEB Program (DEB0213851 and IBN9977063), the Katherine Bisbee II Fund of the Oregon Community Foundation to A.R.B. and a SEED grant from the Declining Amphibian Population Task Force provided to J.M.R. Additional support was provided by an EPA STAR Fellowship (FP-91640201-0) to J.M.R. J. Spatafora provided instruction on isolation of Saprolegnia and use of his laboratory. T. Reed, N. Reed, T. Warren and R. Fitch provided assistance. We also thank M. Jones-Romansic.

\section{LITERATURE CITED}

Alford RA, Richards SJ (1999) Global amphibian declines: a problem in applied ecology. Annu Rev Ecol Syst 30: 133-165

Altizer S, Harvell CD, Friedle E (2003) Rapid evolutionary dynamics and disease threats to biodiversity. Trends Ecol Evol 18:589-596

Baker J, Waights V (1993) The effect of sodium nitrate on the growth and survival of toad tadpoles (Bufo bufo) in the laboratory. Herpetol J 3:147-148

Banks B, Beebee TJC (1988) Reproductive success of natterjack toads Bufo calamita in 2 contrasting habitats. J Anim Ecol 57:475-492

Berger L, Spear R, Hines HB, Marantelli G and 10 others (2004) Effect of season and temperature on mortality in amphibians due to chytridiomycosis. Aust Vet J 82: $434-439$

Biek R, Funk WC, Maxell BA, Mills L S (2002) What is missing in amphibian decline research: insights from ecological sensitivity analysis. Conserv Biol 16:728-734

Blaustein AR, Kiesecker JM (2002) Complexity in conservation: lessons from the global decline of amphibian populations. Ecol Lett 5:597-608

Blaustein AR, Hokit DG, O'Hara RK (1994) Pathogenic fungus contributes to amphibian losses in the Pacific Northwest. Biol Conserv 67:251-254

Blaustein AR, Hatch AC, Belden LK, Kiesecker JM (2004) Mutiple causes for declining amphibian populations. In: Gordon MS, Bartol SM (eds) Experimental approaches to conservation biology. University of California Press, Berkeley, CA, p 35-65

Bly JE, Lawson LA, Szalai AJ, Clem LW (1993) Environmental factors affecting outbreaks of winter saprolegniosis in channel catfish, Ictalurus punctatus (Rafinesque). J Fish Dis 16:541-549

Bragg AN (1962) Saprolegnia on tadpoles again in Oklahoma. Southw Natural 7:79-80

Bragg AN, Bragg WN (1958) Parasitism of spadefoot toads by Saprolegnia. Herpetologica 14:34

Brandi-Dohrn FM, Dick RP, Hess M, Kauffman SM, Hemphill DD Jr, Selker JS (1997) Nitrate leaching under a cereal rye cover crop. J Environ Qual 26:181-188

Brown AF, Pascoe D (1989) Parasitism and host sensitivity to cadmium: an acanthocephalan infection of the freshwater amphipod Gammarus pulex. J Appl Ecol 26:473-488

Camargo JA, Ward JV (1995) Nitrate $\left(\mathrm{NO}_{3}-\mathrm{N}\right)$ toxicity to aquatic life: a proposal of safe concentrations for 2 species of Nearctic freshwater invertebrates. Chemosphere 31: 3211-3216

Carballo M, Muñoz MJ (1991) Effect of sublethal concentrations of four chemicals on susceptibility of juvenile rainbow trout (Oncorhynchus mykiss) to saprolegniosis. Appl Environ Microbiol 57:1813-1816

Carballo M, Muñoz MJ, Tarazona JV (1995) Effects of waterborne copper, cyanide, ammonia, and nitrite on stress parameters and changes in susceptibility to saprolegniosis in Rainbow Trout (Oncorhynchus mykiss). Appl Environ Microbiol 61:2108-2112

Chase JM (2003a) Strong and weak trophic cascades along a productivity gradient. Oikos 101:187-195

Chase JM (2003b) Experimental evidence for alternative stable equilibria in a benthic pond food web. Ecol Lett 6: 733-741

Christin MS, Gendron AD, Brousseau P, Menard L, Marcogliese DJ, Cyr D, Ruby S, Fournier M (2003) Effects of agricultural pesticides on the immune system of Rana 
pipiens and on its resistance to parasitic infection. Environ Toxicol Chem 22:1127-1133

Cleaveland S, Hess GR, Dobson AP, Laurenson MK, McCallum HI, Roberts MG, Woodroffe R (2002) The role of pathogens in biological conservation. In: Rizzoli A, Grenfell BT, Heesterbeek H, Dobson AP (eds) The ecology of wildlife diseases. Oxford University Press, Oxford, p 151-164

Collins JP, Storfer A (2003) Global amphibian declines: sorting the hypotheses. Divers Distrib 9:89-98

Comly HH (1945) Cyanosis in infants caused by nitrates in well-water. J Amer Med Assoc 129:112-116

Daszak P, Cunningham AA, Hyatt AD (2000) Emerging infectious diseases of wildlife: threats to biodiversity and human health. Science 287:443-449

Daszak P, Cunningham AA, Hyatt AD (2003) Infectious disease and amphibian population declines. Divers Distrib 9: $141-150$

Fuller MS, Jaworski A (eds) (1987) Zoosporic fungi in teaching \& research. Southeastern Publishing Corporation, Athens, GA

Gendron AD, Marcogliese DJ, Barbeau S, Christin MS, Brousseau P, Ruby S, Cyr D, Fournier M (2003) Exposure of leopard frogs to a pesticide mixture affects life history characteristics of the lungworm Rhabdias ranae. Oecologia 135:469-476

Giblin AE, Gaines AG (1990) Nitrogen inputs to a marine embayment: the importance of groundwater. Biogeochemistry 10:309-328

Gog J, Woodroffe R, Swinton J (2002) Disease in endangered metapopulations: the importance of alternative hosts. Proc R Soc Lond B Biol Sci 269:671-676

Gosner KL (1960) A simplified table for staging anuran embryos and larvae with notes on identification. Herpetologica 16:183-190

Grossholz ED (1992) Interactions of intraspecific, interspecific, and apparent competition with host-pathogen population dynamics. Ecology 73:507-514

Guth DJ, Blankespoor HD, Cairns J Jr (1977) Potentiation of zinc stress caused by parasitic infection of snails. Hydrobiologia 55:225-229

Harvell CD, Mitchell CE, Ward JR, Altizer S, Dobson AP, Ostfeld RS, Samuel MD (2002) Climate warming and disease risks for terrestrial and marine biota. Science 296: 2158-2162

Hatch AC, Blaustein AR (2000) Combined effects of UV-B, nitrate, and low $\mathrm{pH}$ reduce the survival and activity level of larval Cascades frogs (Rana cascadae). Arch Environ Contam Toxicol 39:494-499

Hatch AC, Blaustein AR (2003) Combined effects of UV-B radiation and nitrate fertilizer on larval amphibians. Ecol Appl 13:1083-1093

Hatch AC, Belden LK, Scheesele EA, Blaustein AR (2001) Juvenile amphibians do not avoid potentially lethal levels of urea on soil substrate. Environ Toxicol Chem 20: 2328-2335

Hecnar SJ (1995) Acute and chronic toxicity of ammonium nitrate fertilizer to amphibians from southern Ontario. Environ Toxicol Chem 14:2131-2137

Houlahan JE, Findlay CS, Schmidt BR, Myer AH, Kuzmin SL (2000) Quantitative evidence for global amphibian population declines. Nature 404:752-755

Huey DW, Beitinger TL (1980) Hematological responses of larval Rana catesbeiana to sublethal nitrate exposures. Bull Environ Contam Toxicol 25:574-577

Johnson PTJ, Chase JM (2004) Parasites in the food web: linking amphibian malformations and aquatic eutrophication
Ecol Lett 7:521-526

Johnson PTJ, Lunde KB, Thurman EM, Ritchie EG and 6 others (2002) Parasite (Ribeiroia ondatrae) infection linked to amphibian malformations in the western United States. Ecol Monogr 72:151-168

Khan RA (1990) Parasitism in marine fish after chronic exposure to petroleum hydrocarbons in the laboratory and to the Exxon Valdez oil spill. Bull Environ Contam Toxicol 44:759-763

Kiesecker JM (2002) Synergism between trematode infection and pesticide exposure: a link to amphibian limb deformities in nature? Proc Natl Acad Sci USA 99:9900-9904

Kiesecker JM, Blaustein AR (1995) Synergism between UV-B radiation and a pathogen magnifies amphibian embryo mortality in nature. Proc Natl Acad Sci USA 92: 11049-11052

Kiesecker JM, Blaustein AR (1997) Influences of egg laying behavior on pathogenic infection of amphibian eggs. Conserv Biol 11:214-220

Kiesecker JM, Blaustein AR (1999) Pathogen reverses competition between larval amphibians. Ecology 80: $2442-2448$

Kiesecker JM, Skelly DK (2001) Effects of disease and pond drying on gray tree frog growth, development, and survival. Ecology 82:1956-1963

Kiesecker JM, Blaustein AR, Belden, LK (2001a) Complex causes of amphibian population declines. Nature 410: 681-684

Kiesecker JM, Blaustein AR, Miller CL (2001b) Transfer of a pathogen from fish to amphibians. Conserv Biol 15: 1064-1070

Lafferty KD, Holt RD (2003) How should environmental stress affect the population dynamics of disease? Ecol Lett 6: 654-664

Lee DHK (1970) Nitrates, nitrites, and methemoglobinemia. Environ Res 3:484-511

Lefcort H, Hancock KA, Maur KM, Rostal DC (1997) The effects of used motor oil, silt, and the water mold Saprolegnia parasitica on the growth and survival of mole salamanders (Genus Ambystoma). Arch Environ Contam Toxicol 32:383-388

Lefcort $\mathrm{H}$, Aguon MQ, Bond KA, Chapman KR and 5 others (2002) Indirect effects of heavy metals on parasites may cause shifts in snail species compositions. Arch Environ Contam Toxicol 43:34-41

MacGregor ME (1921) The influence of the hydrogen-ion concentration in the development of mosquito larvae. Parasitology 13:348-351

Marco A, Quilchano C, Blaustein AR (1999) Sensitivity to nitrate and nitrite in pond-breeding amphibians from the Pacific northwest, USA. Environ Toxicol Chem 18: 2836-2839

McCallum H, Dobson AP (2002) Disease, habitat fragmentation and conservation. Proc R Soc Lond B Biol Sci 269: 2041-2049

Mitchell CE, Tilman D, Groth JV (2002) Effects of grassland species diversity, abundance, and composition on foliar fungal disease. Ecology 83:1713-1726

Muir PR, Sutton DC, Owens L (1991) Nitrate toxicity to Penaeus monodon protozoea. Mar Biol 108:67-71

OECD (Organisation for Economic Cooperation and Development) (1982) Eutrophication of waters: monitoring, assessment, and control. Organisation for Economic and Cooperative Development, Paris

Parris MJ, Baud DR (2004) Interactive effect of a heavy metal and chytridiomycosis on gray treefrog larvae. Copeia 2004:344-350 
Pickering AD (1994) Factors which predispose salmonid fish to saprolegniasis. In: Mueller GJ (ed) Salmon saprolegniasis. US Dept of Energy, Bonneville Power Administration, Portland, OR, p 67-84

Poleo ABS, Schjolden J, Hansen H, Bakke TA, Mo TA, Rosseland BO, Lydersen E (2004) The effect of various metals on Gyrodactylus salaris (Platyhelminthes, Monogea) infections in Atlantic salmon (Salmo salar). Parasitology 128: 169-177

Richards RH, Pickering AD (1978) Frequency and distribution patterns of Saprolegnia infection in wild and hatcheryreared brown trout Salmo trutta (L.) and char Salvelinus alpinus (L.). J Fish Dis 1:69-82

Riggs MR, Esch GW (1987) The suprapopulation dynamics of Bothriocephalus acheilognathi in a North Carolina cooling reservoir: abundance, dispersion and prevalence. J Parasitol 73:877-892

Riggs MR, Lemly AD, Esch GW (1987) The growth, biomass, and fecundity of Bothriocephalus acheilognathi in a North Carolona cooling reservoir. J Parasitol 73:893-900

Rinella FA, Janet ML (1998) Seasonal and spatial variability of nutrients and pesticides in streams of the Willamette Basin, Oregon, 1993-95. US Geol Surv Water Res Investig Rep 97-4082-C

Rojas S, Richards K, Jancovich JK, Davidson EW (2005) Influence of temperature on Ranavirus infection in larval salamanders Ambystoma tigrinum. Dis Aquat Org 63:95-100

Rouse JD, Bishop CA, Struger J (1999) Nitrogen pollution: an assessment of its threat to amphibian survival. Environ Health Perspect 107:799-803

Semlitsch RD (ed) (2003) Amphibian conservation. Smithsonian Books, Washington, DC

Seymour RL (1970) The genus Saprolegnia. Nova Hedwigia 19:1-124

Steinheimer TR, Scoggin KD, Kramer LA (1998) Agricultural chemical movement through a field-size watershed in Iowa: surface hydrology and nitrate losses in discharge. Environ Sci Technol 32:1048-1052

Strijbosch H (1979) Habitat selection of amphibians during their aquatic phase. Oikos 33:363-372

Stuart SM, Chanson JS, Cox NA, Young BE, Rodrigues ASL, Fischman DL, Waller RW (2004) Status and trends of

Editorial responsibility: Peernel Zwart,

Utrecht, The Netherlands amphibian declines and extinctions worldwide. Science 306:1783-1786

Taylor SK, Williams ES, Mills KW (1999) Effects of malathion on disease susceptibility in Woodhouse's toads. J Wildl Dis 35:536-541

Thornton GJP, Dise NB (1998) The influence of catchment characteristics, agricultural activities, and atmospheric deposition on the chemistry of small streams in the English Lake District. Sci Total Environ 216:63-75

Tilman D, Fargione J, Wolff B, D'Antonio C and 6 others (2001) Forecasting agriculturally driven global environmental change. Science 292:281-284

US EPA (1998) Storage and Retrieval Database (STORET) US Environ Protection Agency, Washington, DC

van Lanen HAJ, Dijksma R (1999) Water flow and nitrate transport to a groundwater-fed stream in the BelgianDutch chalk region. Hydrol Process 13:295-307

Vonesh JR, De la Cruz O (2002a) Complex life cycles and density dependence: assessing the contribution of egg mortality to amphibian declines. Oecologia 133:325-333)

Vonesh JR, De la Cruz O (2002b) Complex life cycles and density dependence: assessing the contribution of egg mortality to amphibian declines. Oecologia 133:627

Walls SC, Jaeger RG (1987) Aggression and exploitation as mechanisms of competition in larval salamanders. Can J Zool 65:2938-2944

Watt PJ, Oldham RS (1995) The effect of ammonium nitrate on the feeding and development of larvae of the smooth newt, Triturus vulgaris (L.) and the behaviour of its food source, Daphnia. Freshw Biol 33:319-324

Wentz DA, Bonn BA, Carpenter KD, Hinkle SR and 6 others (1998) Water quality in the Willamette Basin, Oregon, 1991-95. US Geol Sur Circ 1161

Wood SE and Willoughby LG (1986) Ecological observations on the fungal colonization of fish by Saprolegniaceae in Windermere. J Appl Ecol 23:737-749

Woodhams DC, Alford RA, Marantelli G (2003) Emerging disease of amphibians cured by elevated body temperature. Dis Aquat Org 55:65-67

Zhilang S, Qun L, Shumei Z, Hui M, Ping Z (2003) A nitrogen budget of the Changjiang river catchment. Ambio 32: $65-69$

Submitted: June 20, 2005; Accepted: September 22, 2005

Proofs received from author(s): February 16, 2006 